\title{
Health Risk Assessment of Physical and Chemical Hazards in the Painting Area of a Manufacturing Company
}

\author{
Analisis Risiko Kesehatan Bahaya Fisika dan Kimia Area Painting di Perusahaan \\ Manufaktur
}

\author{
Aulia Indar Ayuningtyas, Sjahrul M. Nasri \\ Departement of Occupational Health and Safety, Faculty of Public Health, University of Indonesia \\ C Building 2nd Floor Kampus Baru Universitas Indonesia Depok 16424, Indonesia
}

\begin{abstract}
Introduction: The work process of the Painting Area in a Manufacturing Company can pose a risk to physical and chemical health hazards for workers. Hazard analysis and identification, exposure assessment, and risk assessment are, therefore, needed to protect the health of workers from these health hazards, which can later be used as a basis to determine appropriate controls so as not to have a negative impact on workers' health. The purpose of this study was to analyze the hazards and their impacts on workers' health through hazard identification measures, exposure assessments, risk assessments and control recommendations. Methods: Health Risk Assessment of physical and chemical hazards in the Painting Area was undertaken using a semi-quantitative method by calculating a risk assessment matrix using the guidelines from IPIECA \& OGP in 2016. Results: Physical hazards were found in the form of lighting hazards, vibrations (arm vibration and whole body vibration), noise and heat pressure. Meanwhile, chemical hazards were found in the form of thinner vapor, solvent, $\mathrm{NaNO}_{3}, \mathrm{H}_{2} \mathrm{SO}_{4}, \mathrm{NaOH}, \mathrm{H}_{3} \mathrm{NSO}_{4}$ and indoor air quality $\left(\mathrm{CO}, \mathrm{NO}_{2}, \mathrm{SO}_{2}, \mathrm{H}_{2} \mathrm{~S}\right)$. The results of the risk assessment matrix obtained 4 levels of risk hazards, consisting of $11.1 \%$ in the first priority, 50\% in the second priority, $25.9 \%$ in the third priority and $12.9 \%$ in the condition that did not require immediate action. Conclusion: Physical and chemical health hazards were at 4 levels based on the calculation of risk control priorities. A hierarchy of risk control could be used to reduce the risk of health hazards.
\end{abstract}

Keywords: health risk assessment, ipieca \& ogp 2016, painting area, risk assessment matrix

\begin{abstract}
ABSTRAK
Pendahuluan: Proses kerja di Area Painting Perusahaan Manufaktur dapat menimbulkan risiko bahaya kesehatan fisik dan kimia bagi pekerja. Diperlukan analisis dan identifikasi bahaya, penilaian pajanan, penilaian risiko untuk melindungi kesehatan pekerja dari risiko bahaya kesehatan yang dapat digunakan sebagai pedoman untuk menentukan pengendalian yang tepat agar tidak berdampak negatif bagi kesehatan pekerja. Tujuan penelitian ini adalah untuk menganalisis bahaya dan dampaknya terhadap kesehatan pekerja melalui langkah-langkah identifikasi bahaya, penilaian paparan, penilaian risiko dan rekomendasi pengendalian. Metode: Penilaian Risiko Kesehatan bahaya fisik dan kimiawi di Painting Area dilakukan dengan metode semi kuantitatif dengan menghitung matriks penilaian risiko menggunakan pedoman dari IPIECA \& OGP tahun 2016. Hasil: Bahaya fisik yang ditemukan berupa bahaya pencahayaan, getaran (getaran lengan tangan dan getaran seluruh tubuh), kebisingan dan tekanan panas. Sedangkan bahaya kimiawi berupa uap Thinner, Solvent, $\mathrm{NaNO}_{3}, \mathrm{H}_{2} \mathrm{SO}_{4}, \mathrm{NaOH}, \mathrm{H}_{3} \mathrm{NSO}_{4}$ dan kualitas udara dalam ruangan (CO, $\mathrm{NO}_{2}, \mathrm{SO}_{2}, \mathrm{H}_{2} \mathrm{~S}$ ). Hasil risk assessment matriks didapatkan 4 tingkat bahaya risiko, terdiri dari 11,1\% pada prioritas pertama, 50\% pada prioritas kedua, 25,9\% pada prioritas ketiga dan 12,9\% tidak memerlukan tindakan segera. Simpulan: Bahaya kesehatan fisik dan kimiawi berada pada 4 level berdasarkan perhitungan prioritas pengendalian risiko. Untuk mengurangi resiko bahaya kesehatan dapat menggunakan hirarki pengendalian risiko.
\end{abstract}

Kata kunci: area painting, ipieca \& ogp 2016, matriks penilaian risiko, penilaian risiko kesehatan

Corresponding Author:

Aulia Indar Ayuningtyas

Email: auliaindar94@gmail.com

Telephone: +6285728942528

\section{INTRODUCTION}

Based on information from the International Labor Organization (ILO) in 2013, it was found that 1 expert in the world died every 15 second due to work accidents, and 160 laborers experienced work- 
related illnesses. Other data from The Bureau of Labor of Statistics in 2016 asserted that there were 0.9 cases per 100 workers who experienced injuries and occupational diseases (PAK) in the oil and gas production sector. Meanwhile, in the national scale, in Indonesia, a survey of 26 provinces found that throughout 2013 there were 2,998,766 cases of work accidents and 428,844 cases of work-related illnesses (Ministry of Health, 2015).

In accordance with a report from the Indonesian Ministry of Health, it is revealed that potential health problems for workers are work accidents, workrelated ilnesses, non-communicable diseases and infectious diseases (Ministry of Health, 2015).

Based on the information released by The Bureau of Labor of Insights, in 2019 there were 2.8 cases per 100 fulltime identical laborers, which was the rate recordedin 2018 and 2017. Manufacturing accounted for 15.0 percent of all private industry nonfatal injuries and illnesses in 2019 and was the only private industry segment where the total recordable cases (TRC) rate changed significantly throughout the year. The rate decreased from 3.4 in 2018 to 3.3 cases per 100 full-time equivalent (FTE) workers in 2019.

PT X is an automotive manufacturing company engaged in the manufacture of all types of chassis for trucks and buses. One of the work areas at the Manufacturing Company is an Area of Painting which has potential hazards that can pose a risk of health problems. In the production process, the Painting Area consists of various working processes, including loading side rails, loading materials, weaping materials, operating the paintings, operating the ovens, operating the air compressors, testing the products in the laboratory and draining the chemical tanks. However, the dominant potential hazards in the area are the physical factors of vibration, lighting, noise and heat stress as well as chemical factors from the chemical vapor used and indoor air quality. These potential hazards can affect the health conditions of workers in the work environment and are at risk of causing occupational diseases.

To protect workers from these health risks, it is necessary to have a health risk assessment. The evaluation of risk incorporates both an assessment of the likelihood that a danger may cause harm to human health and an assessment of the potential seriousness of the possible harm caused by the danger (Rout and Sikdar, 2017). Besides, to fulfill the standards and requirements of the health of the industrial work environment, every industry must do monitoring in the form of risk analysis in the environmental media periodically (Ministry of Manpower, 2018). Health risk assessment takes an opportunity-based approach and applies it to the hazards associated with health hazards. It includes a human health perspective as defined by the physical, chemical, organic and social components in the environment. Meanwhile, the evaluation risk gives us data to create reasoned choices in relation to recognizing and tackling the potential impacts of hazards on our health. Morever, hazard evaluation will collect and assess accessible and important data about the potential health impacts in a consistent and objective way. The data can be further utilized within the preparation for hazard management where choices about how to best actions are made (Western Australia Department of Health, 2006). Based on this situation, the researcher is interested in conducting Health Risk Assessment research in the Painting Area of a Manufacturing Company.

\section{METHODS}

This study was conducted in the Painting Area of a Manufacturing Company, an automotive company engaged in the manufacture of all types of chassis for trucks and buses. The study was conducted from November to December 2020 by observing and assessing the risk of health hazards.

The health risk assessment is a process for assessing workplace health risks. The goal of occupational HRA is to identify health hazards systematically and proactively, assess potential health risks and determined appropiate control measures to protect workers' health (ICMM, 2016). To be able to compile a comprehensive Health Risk Assessment (HRA), a systematic method is needed so that the preparation of HRA and HRA results could be easily understood by the related parties The method used in conducting the Health Risk Assessment (HRA) in this study was through the use of guidelines of IPIECA \& OGP in 2016.

HRA must cover and be applied to all workers, contractors and third parties in the work environment. It is recommended that HRA be carried out during the initial process of doing work, periodically and repeatedly if there are changes or requests from the Law. Meanwhile, the stages and processes of implementing a Health Risk Assessment (HRA) include the identification of health hazards in the workplace, health hazard assessment and risk control. 
The steps to carry out a health risk assessment in accordance with the 2016 IPIECA \& OGP were the identification of hazard, health hazards asessment, and recommendation of controls. The identification or recognition of health hazards was necessary to determine the hazards that originated from the workplace by determining occupations, tasks and activities of the workers. After the identification of the work process as well as the number and characteristics of the workers, the existing hazards were identified based on the workers' assumptions on exposure. There were four ways to identify hazards: first, walk-through surveys, which is is most frequently used method; second, information from safety data sheet or other sources; third understanding of the work process and the materials used or produced; and fourth, health problems from the results of health checks and workers' complaints through the process of reviewing their relationship to the hazard that caused them (Kurniawidjaja, 2012).

Hazard identification is the process of identifying sources, situations or actions that have the potential to cause accidents, health problems or a combination of both and of determining the characteristics of these hazards. Hazards can be identified through quantitative methods (data driven) and qualitative methods (discussion and interviews) (ISO 45001, 2018).

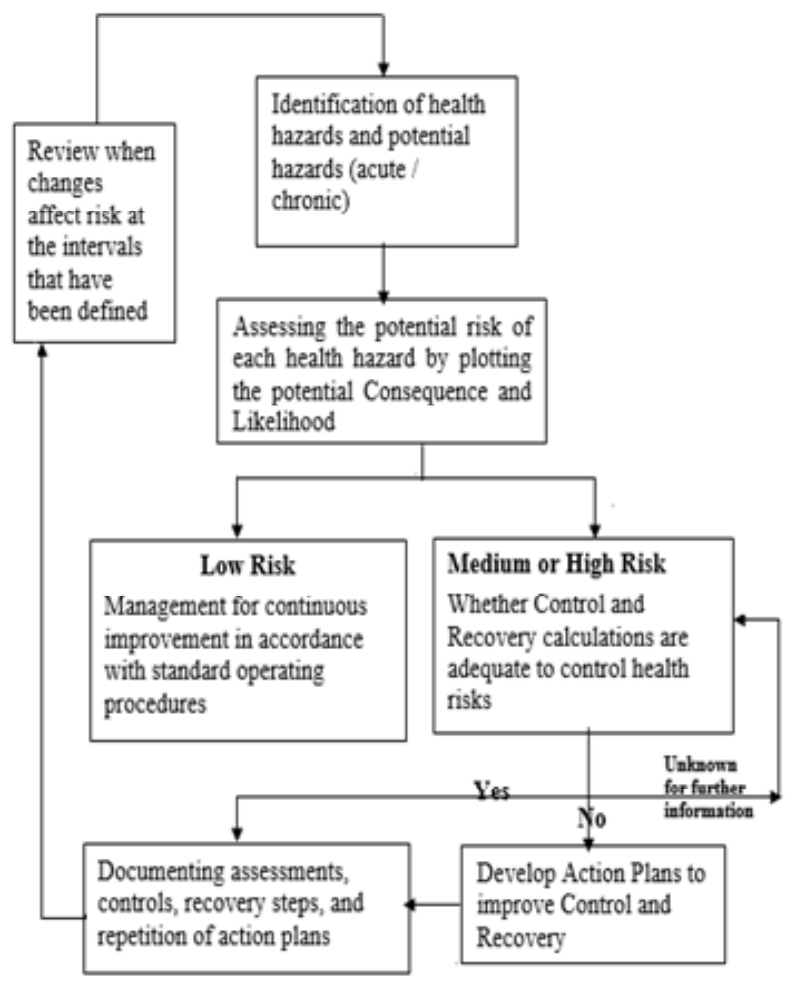

Figure 1. HRA Process Diagram According to IPIECA \& OGP
In the IPIECA \& OGP (2016), it is explained that several aspects must be considered when identifying health hazards, including looking at the work area and reviewing design plans; looking at previous records about area specifications, accidents that have occurred and the future steps; and reviewing sources of health hazard information.

The first step was the process of identifying health hazards, it is necessary to consider all parts of the work to determine future health hazards. In this study, health hazards were classified as chemical, physical, biological, ergonomic, and psychological hazards. To initiate a health risk assessment, walkthrough survey was carried out in the work area. Several factors that had to be identified from health hazardsare the effects of hazards, acute or chronic classification, way of exposure to the body, contact with skin and eyes, inhalation, hearing and so on.

The second step was assessing health hazards. In assessing health hazards, each health hazard would be assessed and it would be plotted in the Risk Assessment Matrix (RAM), which had a function to prioritize potential health risks and determine risks after control was carried out. The

Table 1. Hazard Rating Categories (Severity) according to IPIECA \& OGP

\begin{tabular}{cl}
\hline $\begin{array}{c}\text { Assessment of } \\
\text { Hazard (C) }\end{array}$ & $\begin{array}{l}\text { Definition (Consequence Category: } \\
\text { Danger to Human) }\end{array}$ \\
\hline 1 & $\begin{array}{l}\text { Minor health effects: Agents do not affect } \\
\text { performance or cause disability, e.g., non } \\
\text { toxic dust (as an acute hazard). }\end{array}$ \\
\hline 2 & $\begin{array}{l}\text { Mild health effects: Agents lead to minor } \\
\text { health effects that are reversible, e.g., } \\
\text { irritating agents, defatting agents, many } \\
\text { bacteria, and food poisoning. }\end{array}$ \\
\hline 3 & $\begin{array}{l}\text { Major health effects: Agents are able to } \\
\text { irreversibly damage health without losing } \\
\text { life, for example noise, poor manual } \\
\text { handling, hand / arm vibration, and } \\
\text { chemicals causing systemic effects. }\end{array}$ \\
\hline $\begin{array}{l}\text { One to three fatalities or permanent } \\
\text { disability: Agents are capable of } \\
\text { damaging permanently with serious } \\
\text { disability or death, for example corrosive } \\
\text { materials, carcinogens for humans (slight } \\
\text { degree of exposed populations), agents } \\
\text { that threaten work continuity, heat, cold, } \\
\text { psychological stress. }\end{array}$ \\
\hline $\begin{array}{l}\text { Severalfatalities: Agents with thepotential } \\
\text { to cause multiple fatalities, for example } \\
\text { chemicals with an acute toxic effect } \\
\text { (hydrogen sulfide, carbon monoxide), } \\
\text { which is known as carcinogens to humans } \\
\text { (exposed populations). }\end{array}$ \\
\hline 5
\end{tabular}


calculation formula was $\mathrm{RAM}=\mathrm{C} \mathrm{x} \mathrm{L}$ where $\mathrm{C}$ is the consequence and $\mathrm{L}$ is the likelihood and RAM is the Risk Assessment Matrix. In determining the consequence, a consequence analysis of the hazard category for humans was assessed, whether the consequence was at the level of minor health effects, mild health effects, major health effects, one to three casualties or permanent disability, or even multiple fatalities. The determination of the consequence category in the Risk Assessment Matrix (RAM) needs to be noted the danger to people, company assets and reputation. In addition, it is necessary to look at the regulations governing these hazards, the risks that are acceptable to workers and the control that has been existed.

Meanwhile, to determine the likelihood, exposure rating analysis was undertaken based on the effectiveness assessed from the on-site control. The levels for the likelihood were very low, low, moderate, high and very high.

Table 2. Exposure Rating (Likelihood) according to IPIECA \& OGP

\begin{tabular}{|c|c|c|c|}
\hline $\begin{array}{l}\text { Exposure } \\
\text { Rating }\end{array}$ & Exposure & Likelihood & Definition \\
\hline $\begin{array}{l}\text { Very Low } \\
\text { (a) }\end{array}$ & $<0,1 \times \mathrm{NAB}$ & $\begin{array}{l}\text { Never happen } \\
\text { in the industry }\end{array}$ & $\begin{array}{l}\text { Exposure can be } \\
\text { ignored }\end{array}$ \\
\hline Low (b) & $<0,5 \times \mathrm{NAB}$ & $\begin{array}{l}\text { Ever happens } \\
\text { in the industry }\end{array}$ & $\begin{array}{l}\text { Exposure is } \\
\text { controlled under } \\
\text { the TLV and } \\
\text { will remain so } \\
\text { according to the } \\
\text { standards }\end{array}$ \\
\hline $\begin{array}{l}\text { Moderate } \\
\text { (c) }\end{array}$ & $\begin{array}{c}>0,5-1 x \\
\text { NAB }\end{array}$ & $\begin{array}{l}\text { Has ever } \\
\text { occurred in } \\
\text { organizations, } \\
\text { more than } \\
\text { once per year } \\
\text { in industry }\end{array}$ & $\begin{array}{l}\text { Exposure is } \\
\text { controlled under } \\
\text { TLV currently, } \\
\text { yet controls may } \\
\text { not be as strong } \\
\text { as personal } \\
\text { p r o t e c t i v e } \\
\text { equipment }\end{array}$ \\
\hline High (d) & $>\mathrm{NAB}$ & $\begin{array}{l}\text { Has occurred } \\
\text { at a location, } \\
\text { more than once } \\
\text { per year in the } \\
\text { organization }\end{array}$ & $\begin{array}{l}\text { Exposure is } \\
\text { not controlled } \\
\text { sufficiently } \\
\text { to meet the } \\
\text { standards and } \\
\text { continuously } \\
/ \text { routinely } \\
\text { exceeds TLV }\end{array}$ \\
\hline $\begin{array}{c}\text { Very } \\
\text { High (e) }\end{array}$ & $>$ NAB & $\begin{array}{l}\text { Has ever } \\
\text { occured } \\
\text { more than } \\
\text { once per year } \\
\text { at a location }\end{array}$ & $\begin{array}{l}\text { Ex c e s s ive } \\
\text { exposure will } \\
\text { almost certainly } \\
\text { result in health } \\
\text { damage to the } \\
\text { affected person }\end{array}$ \\
\hline
\end{tabular}

After analyzing the consequence and likelihood, the determination of the risk rank began based on the results of the determination of the first priority for action, the second priority, the third priority and the condition that did not require immediate action.

The third step was recommendation of control. Hazard has the potential to emerge a risk of loss. If the potential is large, it means the risk involved is also greater and unacceptable. Therefore, joint management of workers is obliged to carry out risk control by reducing or eliminating risks in the workplace. The purpose of risk control is the creation of a proper workplace for workers' health and safety (Kurniawidjaja,2012).

Risk control can be carried out through various methods, namely: technical or engineering controls, including elimination; substitution; isolation; ventilation (engineering control); education and training; awareness and motivation building which includes a bonus system, incentives, rewards, selfmotivation; and evaluation through internal audit, investigation and etiology (Ministry of Manpower, 2012)

It is different with IPIECA \& OGP which state that there are several actions that can be taken as risk control in accordance with the specified risk level. The first priority action that can be taken is to stop the exposure, notify the management as soon as possible, identify all sources of danger, and implement corrective controls such as the use of personal protective equipment until the next control action. In this case, it is necessary to calculate the exposure and review the HRA, including the calculation after the improvement.

Tabel 3. Risk Assessment Matrix

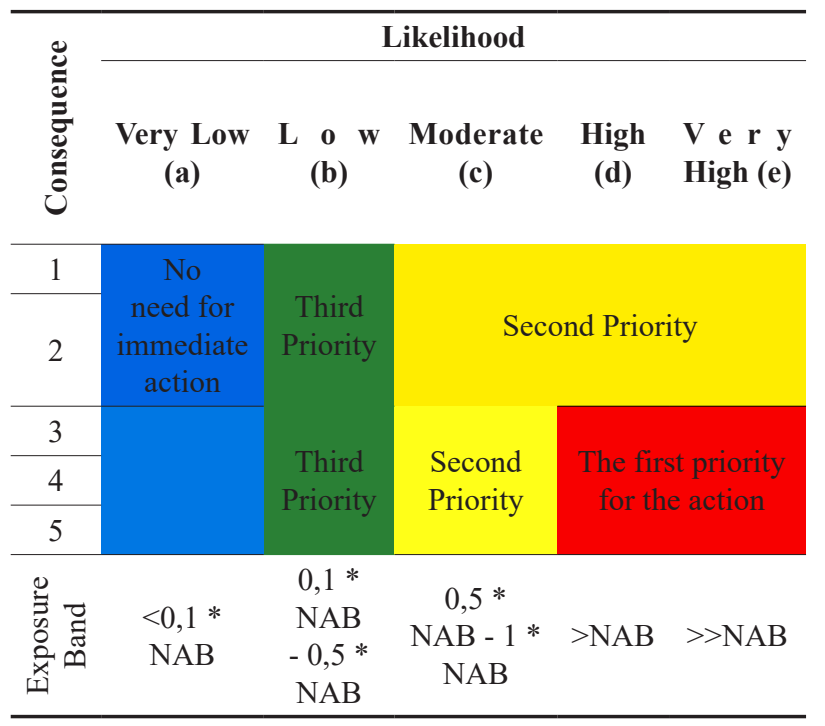


Actions for the second priority include reducing the number of exposures to be below TLV (Rating 1-2) and reducing it to below $0.5 \times$ TLV (Raing 3-5), using personal protective equipment until better control measures are taken, identifying and implementing work guidelines and improvement of controls (hierarchy of control required), and reviewing the HRA, including calculations after improvements are made.

Actions for the third priority are identifying and implementing work guidelines, improvement of controls, and assessment of exposure; and reviewing HRA including calculation of exposure after improvement where there is usually no need for immediate action on better controls.

Remedial actions that can be taken in this case include remedial measures (preparedness) which aims to reduce the potential impact if exposure control measures fail, and to prevent potential increases in health risks. Measures to reduce the likelihood of an escalation (an increase) of incidents when controls fail should be included in a medical emergency response plan wherein the specifications for remedial measures must also be identified, such as control measures. Decisions about adequacy are also required.

\section{RESULTS}

Potential physical and chemical hazards found from the identification results in the Painting Area includedthe following activities: loading siderails, loading materials, weaponing materials, moving materials to the loading painting area, painting operations, operating ovens, operating the air compressors, checking materials in the laboratory, and adding chemical materials and chemical dewatering in the chemical tanks. Moreover, based on the identification results, physical hazards were found in the form of lighting exposure, hand arm vibration (HAV), whole body vibration (WBV), noise and heat pressure. Meanwhile, the chemical hazard factors were vapor from Thinner, Solvent, $\mathrm{NaNO}_{3}, \mathrm{H}_{2} \mathrm{SO}_{4}, \mathrm{NaOH}, \mathrm{H}_{3} \mathrm{NSO}_{4}$ and Indoor Air Quality $\left(\mathrm{CO}, \mathrm{NO}_{2}, \mathrm{SO}_{2}, \mathrm{H}_{2} \mathrm{~S}\right)$.

The health risk assessment analysis was carried out in the Painting Area at the Manufacturing Company after the hazard identification. From this analysis, 54 potential physical and chemical hazards were identified. The risk assessment result of the physical hazards was $27(50 \%)$. Analysis of the hazard assessment for each priority showed that there were 4 in the first priority $(15 \%), 13$ in the second priority (48\%), 8 in the third priority $(30 \%)$ and 2 which did not need immediate action (7\%). Regarding chemical hazards, 27 (50\%) hazards were identified with, based on the results of the assessment analysis, 2 in the first priority (7\%), 14 in the second priority (52\%), 6 in the third priority $(22 \%)$, and 5 which did not need immediate action (19\%).

Based on the Risk Assessment Matrix (RAM) results, it was found that 4 potential physical and chemical hazards in the Painting Area were obtained, namely $6(11.1 \%)$ in the first priority, $27(50 \%)$ in the second priority, $14(25.9 \%)$ in third priority and 7 in the condition $(12.9 \%)$ which did not require

Table 4. Results of Health Hazard Identification in the Painting Area of a Manufacturing Company

\begin{tabular}{|c|c|c|}
\hline \multirow{2}{*}{ Type of work } & \multicolumn{2}{|c|}{ Health Hazard } \\
\hline & Physical & Chemical \\
\hline $\begin{array}{ll}\text { Loading } & \text { siderails } \\
\text { and } & \text { Loading } \\
\text { materials } & \end{array}$ & $\begin{array}{l}\text { Heat Stress, } \\
\text { Lighting, Noise }\end{array}$ & - \\
\hline Weaping materials & $\begin{array}{l}\text { Heat Stress, } \\
\text { Lighting, Noise }\end{array}$ & $\begin{array}{l}\text { Indoor air quality } \\
\left(\mathrm{CO}, \mathrm{NO}_{2}, \mathrm{SO}_{2} \text {, }\right. \\
\left.\mathrm{H}_{2} \mathrm{~S}\right)\end{array}$ \\
\hline $\begin{array}{l}\text { Moving materials } \\
\text { to the loading } \\
\text { Painting area }\end{array}$ & $\begin{array}{l}\text { Heat Stress, } \\
\text { Lighting, Noise }\end{array}$ & $\begin{array}{l}\text { Indoor air quality } \\
\left(\mathrm{CO}, \mathrm{NO}_{2}, \mathrm{SO}_{2},\right. \\
\left.\mathrm{H}_{2} \mathrm{~S}\right)\end{array}$ \\
\hline $\begin{array}{l}\mathrm{O} p \text { e } \mathrm{r} \text { a } \mathrm{t} \mathrm{i} \mathrm{g} \\
\text { machines in the } \\
\text { Painting area }\end{array}$ & $\begin{array}{ll}\text { Whole } & \text { Body } \\
\text { Vibration, } & \\
\text { Heat } & \text { Stress, } \\
\text { Lighting, } & \\
\text { Noise } & \end{array}$ & $\begin{array}{lr}\text { Steam } & \text { from } \\
\text { Thinner, Solvent, } & \mathrm{NaNO}_{3}, \mathrm{H}_{2} \mathrm{SO}_{4}, \\
\mathrm{NaOH}, \mathrm{H}_{3} \mathrm{NSO}_{4}\end{array}$ \\
\hline Operating ovens & $\begin{array}{l}\text { Whole Body } \\
\text { Vibration, } \\
\text { Heat Stress, } \\
\text { Noise }\end{array}$ & - \\
\hline $\begin{array}{l}\text { Operating the air } \\
\text { compressors }\end{array}$ & $\begin{array}{l}\text { Hand } \\
\text { vibration, } \\
\text { Heat Stress, } \\
\text { Noise }\end{array}$ & - \\
\hline $\begin{array}{l}\mathrm{C} \text { o n d u c t i n g } \\
\text { materialinspection } \\
\text { and product testing } \\
\text { in the Painting } \\
\text { laboratory }\end{array}$ & $\begin{array}{l}\text { Heat Stress, } \\
\text { Lighting }\end{array}$ & \\
\hline $\begin{array}{l}\text { Adding chemicals } \\
\text { to the painting } \\
\text { operation tank }\end{array}$ & $\begin{array}{l}\text { Heat Stress, } \\
\text { Lighting, } \\
\text { Noise }\end{array}$ & $\begin{array}{lr}\text { Vapor } & \text { from } \\
\text { Thinner, Solvent, } & \mathrm{NaNO}_{3}, \mathrm{H}_{2} \mathrm{SO}_{4} \text {, } \\
\mathrm{NaOH}, \mathrm{H}_{3} \mathrm{NSO}_{4}\end{array}$ \\
\hline $\begin{array}{l}\text { Draining the } \\
\text { chemical tanks }\end{array}$ & Heat Stress & $\begin{array}{lr}\text { Vapor } & \text { from } \\
\text { Thinner, } & \text { Solvent, } \\
\mathrm{NaNO}_{3}, & \mathrm{H}_{2} \mathrm{SO}_{4}, \\
\mathrm{NaOH}, \mathrm{H}_{3} \mathrm{NSO}_{4}\end{array}$ \\
\hline
\end{tabular}


Table 5. Measurement of hazard exposures and duration of work in the Painting Area

\begin{tabular}{|c|c|c|c|c|}
\hline \multirow{2}{*}{$\begin{array}{l}\text { Type of } \\
\text { Work }\end{array}$} & \multicolumn{2}{|c|}{ Health Hazard } & \multirow{2}{*}{$\begin{array}{l}\text { Measurement } \\
\text { result }\end{array}$} & \multirow[t]{2}{*}{ Duration } \\
\hline & Physical & Chemical & & \\
\hline \multirow{2}{*}{$\begin{array}{l}\text { Loading } \\
\text { siderails }\end{array}$} & $\begin{array}{l}\text { Heat } \\
\text { stress }\end{array}$ & \multirow[t]{2}{*}{ - } & $28^{\circ} \mathrm{C}$ & \multirow{2}{*}{$\begin{array}{c}\text { Once } \\
\text { every } 30 \\
\text { minutes }\end{array}$} \\
\hline & Noise & & $72.8 \mathrm{~dB}$ & \\
\hline \multirow{3}{*}{$\begin{array}{l}\text { Loading } \\
\text { materials }\end{array}$} & $\begin{array}{l}\text { Heat } \\
\text { stress }\end{array}$ & \multirow{3}{*}{ - } & $29^{\circ} \mathrm{C}$ & \multirow{3}{*}{$\begin{array}{c}\text { Once } \\
\text { every } 15 \\
\text { minutes }\end{array}$} \\
\hline & Lighting & & 256.3 lux & \\
\hline & & & $80.1 \mathrm{~dB}$ & \\
\hline \multirow{9}{*}{$\begin{array}{l}\text { Weaping } \\
\text { materials }\end{array}$} & $\begin{array}{l}\text { Heat } \\
\text { stress }\end{array}$ & & $30^{\circ} \mathrm{C}$ & \multirow{9}{*}{$\begin{array}{c}8 \text { hours a } \\
\text { day }\end{array}$} \\
\hline & Lighting & & $205.3 \operatorname{lux}$ & \\
\hline & Noise & & $82.5 \mathrm{~dB}$ & \\
\hline & \multirow{6}{*}{ - } & $\begin{array}{l}\text { Vapor } \\
\text { from } \\
\text { thinner }\end{array}$ & $\begin{array}{l}\text { Inhalation } \\
\text { of workers } \\
\text { (Occurs more } \\
\text { than once } \\
\text { per year but } \\
\text { includes PPE } \\
\text { use control) }\end{array}$ & \\
\hline & & $\begin{array}{l}\text { Indoor air } \\
\text { quality }\end{array}$ & $1.33 \mathrm{ppm}$ & \\
\hline & & $\mathrm{Co}$ & & \\
\hline & & $\mathrm{No}_{2}$ & $0.001 \mathrm{ppm}$ & \\
\hline & & $\mathrm{So}_{2}$ & $0.05 \mathrm{ppm}$ & \\
\hline & & $\mathrm{H}_{2} \mathrm{~S}$ & $0.001 \mathrm{ppm}$ & \\
\hline \multirow{8}{*}{$\begin{array}{c}\text { Moving } \\
\text { materials } \\
\text { to loading } \\
\text { paintings }\end{array}$} & $\begin{array}{l}\text { Heat } \\
\text { stress }\end{array}$ & & $29^{\circ} \mathrm{C}$ & \multirow{8}{*}{$\begin{array}{c}\text { Once } \\
\text { every } 30 \\
\text { minutes }\end{array}$} \\
\hline & Lighting & & $235.3 \operatorname{lux}$ & \\
\hline & Noise & & $82.5 \mathrm{~dB}$ & \\
\hline & \multirow{5}{*}{ - } & $\begin{array}{l}\text { Indoor air } \\
\text { quality }\end{array}$ & $1.33 \mathrm{ppm}$ & \\
\hline & & $\mathrm{Co}$ & & \\
\hline & & $\mathrm{No}_{2}$ & $0.001 \mathrm{ppm}$ & \\
\hline & & $\mathrm{So}_{2}$ & $0.05 \mathrm{ppm}$ & \\
\hline & & $\mathrm{H}_{2} \mathrm{~S}$ & $0.001 \mathrm{ppm}$ & \\
\hline \multirow{11}{*}{$\begin{array}{l}\text { Operating } \\
\text { machines } \\
\text { in the } \\
\text { Painting } \\
\text { area }\end{array}$} & $\begin{array}{l}\text { Whole } \\
\text { body } \\
\text { vibration }\end{array}$ & \multirow{4}{*}{-} & $0.02640 \mathrm{~m} / \mathrm{s}^{2}$ & \multirow{11}{*}{$\begin{array}{c}8 \text { hours a } \\
\text { day }\end{array}$} \\
\hline & $\begin{array}{l}\text { Heat } \\
\text { stress }\end{array}$ & & $34^{\circ} \mathrm{C}$ & \\
\hline & Lighting & & 665.1 Lux & \\
\hline & Noise & & $90.2 \mathrm{~dB}$ & \\
\hline & \multirow{7}{*}{ - } & $\begin{array}{l}\text { Vapor } \\
\text { from }\end{array}$ & \multirow{7}{*}{$\begin{array}{l}\text { Inhalation } \\
\text { of workers } \\
\text { (Occurs more } \\
\text { than once } \\
\text { per year but } \\
\text { includes PPE } \\
\text { use control) }\end{array}$} & \\
\hline & & Thinner & & \\
\hline & & Solvent & & \\
\hline & & $\mathrm{NaNO}_{3}$ & & \\
\hline & & $\mathrm{H}_{2} \mathrm{SO}_{4}$ & & \\
\hline & & $\mathrm{NaOH}$ & & \\
\hline & & $\mathrm{H}_{3} \mathrm{NSO}_{4}$ & & \\
\hline
\end{tabular}

Advance Table 5

\begin{tabular}{|c|c|c|c|c|}
\hline \multirow{2}{*}{$\underset{\text { Work }}{\text { Type of }}$} & \multicolumn{2}{|c|}{ Health Hazard } & \multirow{2}{*}{$\begin{array}{l}\text { Measurement } \\
\text { result }\end{array}$} & \multirow[t]{2}{*}{ Duration } \\
\hline & Physical & Chemical & & \\
\hline \multirow{3}{*}{$\begin{array}{l}\text { Opearting } \\
\text { ovens }\end{array}$} & $\begin{array}{l}\text { Whole } \\
\text { body }\end{array}$ & \multirow{3}{*}{ - } & $0.03500 \mathrm{~m} / \mathrm{s}^{2}$ & \multirow{3}{*}{$\begin{array}{c}8 \text { hours a } \\
\text { day }\end{array}$} \\
\hline & $\begin{array}{l}\text { Heat } \\
\text { stress }\end{array}$ & & $34{ }^{\circ} \mathrm{C}$ & \\
\hline & Noise & & $93.4 \mathrm{~dB}$ & \\
\hline \multirow{3}{*}{$\begin{array}{l}\text { Operating } \\
\text { the air } \\
\text { compressors }\end{array}$} & $\begin{array}{c}\text { Hand } \\
\text { Vibration }\end{array}$ & \multirow{3}{*}{-} & $0.02910 \mathrm{~m} / \mathrm{s}^{2}$ & \multirow{3}{*}{$\begin{array}{c}8 \text { hours a } \\
\text { day }\end{array}$} \\
\hline & $\begin{array}{l}\text { Heat } \\
\text { Stress }\end{array}$ & & $33^{\circ} \mathrm{C}$ & \\
\hline & Noise & & $94 \mathrm{~dB}$ & \\
\hline \multirow{2}{*}{$\begin{array}{l}\text { Conducting } \\
\text { Material } \\
\text { inspection } \\
\text { and product } \\
\text { testing in } \\
\text { the Painting } \\
\text { laboratory }\end{array}$} & $\begin{array}{l}\text { Heat } \\
\text { Stress }\end{array}$ & - & $28^{\circ} \mathrm{C}$ & \multirow[b]{2}{*}{$\begin{array}{c}\text { Once } \\
\text { every } 30 \\
\text { minutes }\end{array}$} \\
\hline & Lighting & - & $467.5 \operatorname{lux}$ & \\
\hline \multirow{10}{*}{$\begin{array}{l}\text { Adding } \\
\text { chemicals to } \\
\text { the painting } \\
\text { operation } \\
\text { tanks }\end{array}$} & $\begin{array}{l}\text { Heat } \\
\text { stress }\end{array}$ & \multirow{3}{*}{-} & $34{ }^{\circ} \mathrm{C}$ & \multirow{10}{*}{$\begin{array}{c}\text { Once } \\
\text { every } 30 \\
\text { minutes }\end{array}$} \\
\hline & Lighting & & 665.1 Lux & \\
\hline & Noise & & $90.2 \mathrm{~dB}$ & \\
\hline & \multirow{7}{*}{ - } & $\begin{array}{l}\text { Vapor } \\
\text { from }\end{array}$ & \multirow{7}{*}{$\begin{array}{l}\text { Inhalation } \\
\text { of workers } \\
\text { (Occurs more } \\
\text { than once } \\
\text { per year but } \\
\text { includes PPE } \\
\text { use control) }\end{array}$} & \\
\hline & & Thinner & & \\
\hline & & Solvent & & \\
\hline & & $\mathrm{NaNO}_{3}$ & & \\
\hline & & $\mathrm{H}_{2} \mathrm{SO}_{4}$ & & \\
\hline & & $\mathrm{NaOH}$ & & \\
\hline & & $\mathrm{H}_{3} \mathrm{NSO}_{4}$ & & \\
\hline \multirow{8}{*}{$\begin{array}{l}\text { Draining the } \\
\text { chemical } \\
\text { tanks }\end{array}$} & $\begin{array}{l}\text { Heat } \\
\text { Stress }\end{array}$ & - & $34^{\circ} \mathrm{C}$ & \multirow{8}{*}{$\begin{array}{c}\text { Once } \\
\text { every } 4 \\
\text { month }\end{array}$} \\
\hline & \multirow{7}{*}{ - } & $\begin{array}{l}\text { Vapor } \\
\text { from }\end{array}$ & \multirow{7}{*}{$\begin{array}{l}\text { Inhalation } \\
\text { of workers } \\
\text { (Occurs more } \\
\text { than once } \\
\text { per year but } \\
\text { includes PPE } \\
\text { use control) }\end{array}$} & \\
\hline & & Thinner & & \\
\hline & & Solvent & & \\
\hline & & $\mathrm{NaNO}_{3}$ & & \\
\hline & & $\mathrm{H}_{2} \mathrm{SO}_{4}$ & & \\
\hline & & $\mathrm{NaOH}$ & & \\
\hline & & $\mathrm{H}_{3} \mathrm{NSO}_{4}$ & & \\
\hline
\end{tabular}

immediate action. Hazard risk was dominated by the second priority level where this risk was in a regular process. Therefore, it is necessary to take actions as soon as possible so that the known level based on the research results does not rise to the first level.

Control measures that can be carried out based on the risk assessment findings include the use of a risk control hierarchy, which consists of elimination, substitution, engineering controls, administrative controls and PPE. 
Table 6. Results of Hazard Assessment

\begin{tabular}{|c|c|c|c|c|c|}
\hline \multirow{2}{*}{$\underset{\text { Work }}{\text { Type of }}$} & \multicolumn{2}{|c|}{ Health Hazard } & \multicolumn{2}{|c|}{ Risk } & \multirow{2}{*}{ 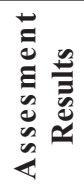 } \\
\hline & Physical & Chemical & C & $\mathbf{L}$ & \\
\hline \multirow{2}{*}{$\begin{array}{l}\text { Loading } \\
\text { siderails }\end{array}$} & Heat stress & \multirow{2}{*}{-} & 3 & b & $3 b$ \\
\hline & Noise & & 3 & $\mathrm{c}$ & $3 \mathrm{c}$ \\
\hline \multirow{3}{*}{$\begin{array}{l}\text { Loading } \\
\text { materials }\end{array}$} & Heat stress & \multirow{3}{*}{-} & 3 & $\mathrm{~b}$ & $3 b$ \\
\hline & Lighting & & 3 & $\mathrm{~b}$ & $3 b$ \\
\hline & Noise & & 3 & $\mathrm{a}$ & $3 a$ \\
\hline \multirow{6}{*}{$\begin{array}{l}\text { Weaping } \\
\text { materials }\end{array}$} & \multirow{6}{*}{ - } & $\begin{array}{l}\text { Vapor } \\
\text { from } \\
\text { thinner }\end{array}$ & 4 & $\mathrm{c}$ & $4 \mathrm{c}$ \\
\hline & & $\begin{array}{c}\text { Indoor air } \\
\text { quality }\end{array}$ & 3 & $\mathrm{c}$ & $3 c$ \\
\hline & & $\mathrm{Co}$ & & & \\
\hline & & $\mathrm{No}_{2}$ & 3 & $\mathrm{~b}$ & $3 b$ \\
\hline & & $\mathrm{So}_{2}$ & 2 & $\mathrm{a}$ & $2 a$ \\
\hline & & $\mathrm{H}_{2} \mathrm{~S}$ & 3 & $\mathrm{c}$ & $3 \mathrm{c}$ \\
\hline \multirow{8}{*}{$\begin{array}{l}\text { Moving } \\
\text { materials } \\
\text { to loading } \\
\text { paintings }\end{array}$} & Heat stress & \multirow{3}{*}{-} & 3 & $\mathrm{~b}$ & $3 b$ \\
\hline & Lighting & & 2 & $\mathrm{~b}$ & $2 b$ \\
\hline & Noise & & 3 & $\mathrm{c}$ & $3 \mathrm{c}$ \\
\hline & \multirow{5}{*}{ - } & $\begin{array}{c}\text { Indoor air } \\
\text { quality }\end{array}$ & 2 & d & $2 d$ \\
\hline & & Co & & & \\
\hline & & $\mathrm{No}_{2}$ & 3 & $\mathrm{a}$ & $3 a$ \\
\hline & & $\mathrm{So}_{2}$ & 3 & $\mathrm{a}$ & $3 a$ \\
\hline & & $\mathrm{H}_{2} \mathrm{~S}$ & 3 & $\mathrm{a}$ & $3 a$ \\
\hline \multirow{10}{*}{$\begin{array}{l}\text { Operating } \\
\text { machines in } \\
\text { the Painting } \\
\text { area }\end{array}$} & $\begin{array}{c}\text { Whole } \\
\text { body } \\
\text { vibration }\end{array}$ & \multirow{4}{*}{ - } & 3 & $\mathrm{~b}$ & $3 b$ \\
\hline & Heat stress & & 3 & $\mathrm{~d}$ & $3 d$ \\
\hline & Lighting & & 3 & $\mathrm{c}$ & $3 \mathrm{c}$ \\
\hline & Noise & & 3 & $\mathrm{c}$ & $3 c$ \\
\hline & \multirow{6}{*}{ - } & $\begin{array}{l}\text { Vapor } \\
\text { from } \\
\text { thinner }\end{array}$ & 4 & $\mathrm{c}$ & $4 c$ \\
\hline & & Solvent & 4 & $\mathrm{c}$ & $4 \mathrm{c}$ \\
\hline & & $\mathrm{NaNO}_{3}$ & 3 & $\mathrm{~b}$ & $3 b$ \\
\hline & & $\mathrm{H}_{2} \mathrm{SO}_{4}$ & 4 & $\mathrm{c}$ & $4 \mathrm{c}$ \\
\hline & & $\mathrm{NaOH}$ & 3 & $\mathrm{c}$ & $3 c$ \\
\hline & & $\mathrm{H}_{3} \mathrm{NSO}_{4}$ & 3 & $\mathrm{c}$ & $3 c$ \\
\hline \multirow{3}{*}{$\begin{array}{l}\text { Operating } \\
\text { ovens }\end{array}$} & $\begin{array}{l}\text { Whole } \\
\text { body } \\
\text { vibration }\end{array}$ & & 4 & $\mathrm{c}$ & $4 \mathrm{c}$ \\
\hline & Heat stress & & 3 & $\mathrm{~d}$ & $3 d$ \\
\hline & Noise & & 3 & $\mathrm{c}$ & $3 c$ \\
\hline \multirow{3}{*}{$\begin{array}{l}\text { Operating } \\
\text { the air } \\
\text { compressors }\end{array}$} & $\begin{array}{c}\text { Hand } \\
\text { Vibration }\end{array}$ & \multirow{3}{*}{ - } & 4 & $\mathrm{c}$ & $4 c$ \\
\hline & $\begin{array}{l}\text { Heat } \\
\text { Stress }\end{array}$ & & 3 & d & $3 \mathrm{~d}$ \\
\hline & Noise & & 3 & $\mathrm{c}$ & $3 c$ \\
\hline
\end{tabular}

Advance Table 6

\begin{tabular}{|c|c|c|c|c|c|}
\hline \multirow{2}{*}{$\begin{array}{c}\text { Type ef } \\
\text { Work }\end{array}$} & \multicolumn{2}{|c|}{ Health Hazard } & \multicolumn{2}{|c|}{ Risk } & \multirow{2}{*}{ 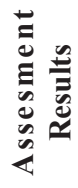 } \\
\hline & Physical & Chemical & $\mathbf{C}$ & $\mathbf{L}$ & \\
\hline \multirow{3}{*}{$\begin{array}{l}\text { Conducting } \\
\text { Material } \\
\text { inspection } \\
\text { and product } \\
\text { testing in } \\
\text { the Painting } \\
\text { laboratory }\end{array}$} & & \multirow{3}{*}{ - } & & & \\
\hline & Heat stress & & 3 & $\mathrm{~b}$ & $3 b$ \\
\hline & Lighting & & 3 & b & $3 b$ \\
\hline \multirow{9}{*}{$\begin{array}{l}\text { Adding } \\
\text { chemicals to } \\
\text { the painting } \\
\text { operation } \\
\text { tanks }\end{array}$} & Heat stress & \multirow{3}{*}{ - } & 3 & b & $3 b$ \\
\hline & Lighting & & 3 & $\mathrm{c}$ & $3 \mathrm{c}$ \\
\hline & Noise & & 3 & $\mathrm{c}$ & $3 \mathrm{c}$ \\
\hline & \multirow{6}{*}{ - } & $\begin{array}{l}\text { Vapor } \\
\text { from } \\
\text { thinner }\end{array}$ & 4 & $\mathrm{c}$ & $4 c$ \\
\hline & & Solvent & 4 & $\mathrm{c}$ & $4 c$ \\
\hline & & $\mathrm{NaNO}_{3}$ & 3 & b & $3 b$ \\
\hline & & $\mathrm{H}_{2} \mathrm{SO}_{4}$ & 4 & $\mathrm{c}$ & $4 \mathrm{c}$ \\
\hline & & $\mathrm{NaOH}$ & 3 & $\mathrm{c}$ & $3 c$ \\
\hline & & $\mathrm{H}_{3} \mathrm{NSO}_{4}$ & 3 & $\mathrm{c}$ & $3 c$ \\
\hline \multirow{7}{*}{$\begin{array}{l}\text { Draining the } \\
\text { chemical } \\
\text { tanks }\end{array}$} & $\begin{array}{l}\text { Heat } \\
\text { Stress }\end{array}$ & - & 4 & $\mathrm{c}$ & $4 c$ \\
\hline & \multirow{6}{*}{ - } & $\begin{array}{l}\text { Vapor } \\
\text { from } \\
\text { thinner }\end{array}$ & 4 & d & $4 d$ \\
\hline & & Solvent & 4 & $\mathrm{c}$ & $4 c$ \\
\hline & & $\mathrm{NaNO}_{3}$ & 3 & d & $3 \mathrm{~d}$ \\
\hline & & $\mathrm{H}_{2} \mathrm{SO}_{4}$ & 4 & $\mathrm{c}$ & $4 \mathrm{c}$ \\
\hline & & $\mathrm{NaOH}$ & 3 & $\mathrm{~b}$ & $3 b$ \\
\hline & & $\mathrm{H}_{3} \mathrm{NSO}_{4}$ & 3 & b & $3 b$ \\
\hline
\end{tabular}

Specifically, an action for the first priority is to implement controls that include engineering controls, administrative controls and the use of personal protective equipment. Further control measures in this case require calculation of exposure and review of HRA, including calculations after improvements. Meanwhile, an action for the second priority is to reduce the amount of exposure to below TLV (Rating 1-2) and reduce it to below $0.5 \times$ TLV (Raing 3-5), use personal protective equipment until better control measures are taken, identify and implement guidelines work and improve control (hierarchy of control required) and conduct a review of HRA, including calculations after improvements are made. The last is an action for the third priority, namely by maintaining safe conditions in the area. This is in accordance with the control recommendations by IPIECA \& OGP 2016. 
Table 7. Results of Health Risk Assessment of Physical and Chemical Hazards in the Painting Area of a Manufacturing Company

\begin{tabular}{ccccccc}
\hline & \multicolumn{5}{c}{ Number of Risk Class } & \\
\cline { 2 - 6 } $\begin{array}{c}\text { Potential } \\
\text { Hazard }\end{array}$ & $\begin{array}{c}\text { No need for } \\
\text { immediate } \\
\text { action }\end{array}$ & $\begin{array}{c}\text { T h i r d } \\
\text { Priority }\end{array}$ & $\begin{array}{l}\text { Second } \\
\text { Priority }\end{array}$ & $\begin{array}{c}\text { F i r s t } \\
\text { Priority }\end{array}$ & \\
\hline Physical & 2 & 8 & 13 & 4 & 27 \\
Chemical & 5 & 6 & 14 & 2 & 27 \\
\hline Total & 7 & 14 & 27 & 6 & 54 \\
\hline
\end{tabular}

\section{DISCUSSION}

\section{Evaluation of the Health Risk Assessment of Physical Hazards in the Painting Area}

The identification of health hazards in the Painting area was followed by an assessment of these hazards, namely by determining the value of the consequence and likelihood of each identified hazard potential. From the hazard assessment, 54 potential physical and chemical hazards were identified. The risk assessment results of the physical hazards was $27(50 \%)$. The hazard assessment analysis for each priority consisted of 4 in the first priority (15\%), 13 in the second priority $(48 \%), 8$ in the third priority $(30 \%)$ and 2 in the category which did not need immediate action (7\%).

Risk assessment aims to see the risks that can be tolerated or cannot be toleratedso that control can be carried out (Zeinda and Hidayat, 2017). Morever, Health Risk Assessment is a process of estimating the potential impact of a chemical, biological, physical, or social agent on a specific human population system under a specific set of conditions and for a specific time frame (Western Australia Department of Health, 2006). The method of assessing risk by calculating the Risk Priority Number (RPN) for each hazard is a quantitative estimate of the risk associated with each hazard. Each hazard is assigned an RPN based on three criteria, which are probability of occurance, severity rate and hierarchy of controls (Saisandhiya, 2020).

From the identification results in this study, it was found that physical hazards were found in the form of lighting exposure, hand arm vibration (HAV), whole body vibration (WBV), noise and heat pressure. Previous research at SMART Ltd. used the HRA in conducting the risk assessment. The results of the research found that the company had a high risk of health problems due to noise, working climate, and lighting (Alifia, 2016). The impact of these physical hazards, if no control measures are taken, will cause health hazards for workers and control measures must be taken immediately. In addition, for the safe execution of activities, possible control measures for identified hazard are recommended (Pawin vivid, Selvakumar and Ruvankumar, 2020).

From the results of health risk assessment of physical hazards in this study, 27 possible hazards that could cause health problems were found. Heat stress was the first priority of physical hazards because the work area was in a building with insufficient ventilation, only equipped with a fan and a small window. If this is not handled immediately, it will have a negative impact on the workers' health. A hot working climate can affect the health of workers, including heat stroke, heat cramps, heat exhaustion, and heat disorder (Lestari, Purba and Camelia, 2017).

Potential hazard of vibration exposure from the health risk assessment results showed that none exceeded the threshold limit value, but if the exposure continues and there is no control it will have a negative impact on workers' health. In a previous research, exposure to WBV can have adverse impacts on back and neck pain, potential cardiovascular diseases, the development of various neuropathies, digestive issues, headaches, dizziness, motion sickness, and cancer, all of which are potential health consequences (Krajnak, 2018). Meanwhile, the potential danger of exposure to lighting in the Painting Area showed that none was less than the threshold limit value. This is because in the painting area, the machine operation is assissted by lighting and the area outside the operating machine also has natural lighting.

The potential hazards of noise exposure that exceeded the threshold value were the area of the painting machines, the operation of the air compressors and the operating area of ovens. The noise which exceeded the threshold value was caused by the production machines and by the position of the machines which was close together, so the noise exposure was directly received by the workers. However, the only control that had been done was using personal protective equipment in the form of earplugs. If the noise exposure exceeds the threshold value, it will be possible to cause health problems to the workers. In one of the previous studies, it is noted that the impact of noise could cause psychological and physiological disorders (Alfathika, Irfandy and Asyari, 2018). 


\section{Evaluation of the Health Risk Assessment of Chemical Hazards in the Painting Area}

The identified chemical hazards were 27 (50\%) with, based on the results of the priority hazard assessment analysis, 2 in the first priority (7\%), 14 in the second priority $(52 \%), 6$ in the third priority $(22 \%)$ and $5(19 \%)$ in the condition which did not need immediate action. Chemical hazard factors in the Painting Area were vapor from Thinner, Solvent, $\mathrm{NaNO}_{3}, \mathrm{H}_{2} \mathrm{SO}_{4}, \mathrm{NaOH}, \mathrm{H}_{3} \mathrm{NSO}_{4}$ and Indoor Air Quality (CO, $\left.\mathrm{NO}_{2}, \mathrm{SO}_{2}, \mathrm{H}_{2} \mathrm{~S}\right)$. The source of these chemical hazards can cause health problems for workers. In oneof the previous studies, benzene and air pollutants were suggested to may be responsible for a significant portion of respiratory diseases, hematologic diseases, and thyroid dysfuntion (Krajnak, 2018). The risk of hazardous chemical factors that were known to affect health included benzene, toluene, ethylbenzene and xylene (BTEX), $\mathrm{CO}, \mathrm{NO}, \mathrm{NO}_{2}$, and $\mathrm{H}_{2} \mathrm{~S}$ (Laal and Noorizadeh, 2017). In another research at PT HIJ, the type of hazards assessed was coal dust in the air (Rizkiani and Modjo, 2018).

From the health risk assessment, none of the identified chemical hazard factors exceeded the threshold value, but there is still a possibility of health problems if the workers are exposed continuously without control. In a previous research on health risk assessment of physical and chemical factors at the Production Collection Center (PPP) PT. Pertamina, for gas chemical factors, the consequences were not very visible because the levels were still below the threshold value set. The gas in the air could still be tolerated by the body because of its low concentration in the air (Jayanti, Sitorus and Purba, 2011).

Health impacts that may occur due to chemical factors in this study are cancer and skin irritation that can potentially occur to workers if the workers repeatedly inhale thiner vapor and are exposed to more than the threshold quantity. Health effects of respiratory system disorders and skin allergies if they are exposed to solvent vapors are skin burns due to $\mathrm{NaNO}_{3}$ vapors, cancer, irritation of the eyes and skin due to $\mathrm{H}_{2} \mathrm{SO}_{4}$ vapors, especially if workers are exposed to continuous large amounts of it. $\mathrm{NaOH}$ vapor and $\mathrm{H}_{3} \mathrm{NSO}_{4}$ vapor in this case have the potential to cause health problems, irritation to the eyes and skin. Meanwhile, indoor air quality $\left(\mathrm{CO}, \mathrm{NO}_{2}, \mathrm{SO}_{2}, \mathrm{H}_{2} \mathrm{~S}\right)$ has health impacts on anemia, impaired lung function, and respiratory tract irritation. Previous research on health risk assessment in the Auto Workshop 2000 showed that Thinner could cause respiratory irritation, eye irritation, dermatitis, headaches, loss of consciousness, kidney and heart problems, and even death (Lestari, Purba and Camelia, 2017).

\section{Recomendations for Control Measures}

Control measures were carried out after hazard identification and risk assessment of these hazards had been carried out. Based on the results of the risk assessment matrix, it was found that hazards were dominated by hazards in the second priority. The current control that has been done by the company is to provide personal protective equipment only. Recommendation of controls that can be carried out to deal with hazards include engineering controls, for example by providing noise absorbers for machines that have an intensity above the threshold value, reducing the amount of exposure to below the threshold value, making a rotation schedule in the area, reducing the frequency of exposure to hazards and using personal protective equipment to take actions.

The outcomes of the risk assessment can be used as a reference and data source in the determination of operation control and administration control to reduce the risk associated with the impacts (Susanto and Mulyono, 2018). A risk reduction plan is developed as part of the risk management process, in which steps are determined to address a specific program risk in order to reduce either its likelihood of occurance, or both, so that the programs's potential impact is reduced (GarcíaGómez, González-Gaya, and Rosales-Prieto, 2020). Risk control principles have been developed in the form of a hierarchy risk control, with the effectiveness of each method. The ability to reduce, minimize, or eliminate risk through the use of a hierarchy of controls must be considered (Iqbal et al., 2021).

The control that can be carried out by the company includes elimination efforts. This is an attempt to eliminate sources of potential hazards from materials, processes, operations or equipment. Meanwhile, substitution is made by changing materials, processes, operations or equipment from dangerous to harmless. The next effort is technical engineering effort which is an effort to separate the source of danger and labor by installing a safety system on tools, machines and work areas. The last one is administrative effort. This is a control 
from the side of the workforce by doing work safely and the use of tools that serve to isolate a part or all of workforce from hazards. In line with previous research, taking exposure control measures including technical control, engineering, management measures, continuous monitoring of the work environment, and risk reassessment after the interventions to minimize the pollutants is highly suggested (Laal and Noorizadeh, 2017).

It is recommended that when controlling chemical risks, a hierarchy be used. If possible, the company should try less risky options (e.g., switching the materials to less hazardous chemicals), subtituting hazards, preventing access to hazards and organizing work to reduce exposure to hazards, using safe working methods, providing welfare facilities and providing workers with free personal protective equipment. Based on the International Labour Organization (2014), it is stated that the recommendation for good control is to use a hierarchy of controls.

The recommendation for control measures based on the results of HRA in the truck chasis assembly plant are engineering controls, administrative controls (job rotation will be practiced, training will be provided for new operators prior to deployment in the stage, and only authorized personnel will operate the machine) and PPE (Pawin vivid, Selvakumar and Ruvankumar, 2020).

\section{CONCLUSION}

Potential physical hazards in the Painting Area of a Manufacturing Company Sidoarjo were in the form of exposure to lighting, hand arm vibration (HAV), whole body vibration (WBV), noise and heat pressure, while those included in the chemical hazard factors were vapor from Thinner, Solvent, $\mathrm{NaNO}_{3}, \mathrm{H}_{2} \mathrm{SO}_{4}, \mathrm{NaOH}, \mathrm{H}_{3} \mathrm{NSO}_{4}$ and Indoor Air Quality $\left(\mathrm{CO}, \mathrm{NO}_{2}, \mathrm{SO}_{2}, \mathrm{H}_{2} \mathrm{~S}\right)$. The level of risk of potential physical and chemical hazards was dominated by 27 hazards in the second priority, so immediate action is needed to prevent the hazard level from increasing to the first priority. The other risk levels consisted of 6 hazards in the first priority, 14 hazards in the third priority and 7 hazards in the category which did not require immediate action. To reduce the level of health risk risk, a hierarchy of control, namely by carrying out a hierarchy of risk control starting from elimination, substitution, engineering engineering, administrative engineering and PPE can be carried out.

\section{ACKNOWLEDGEMENTS}

The author would like to specially thank Mr. Haryadi as the HSE Manager of a Manufacturing Company, Sidarjo for the assistance during the accomplishment of this research.

\section{REFERENCES}

Alfathika, D., Irfandy, D. and Asyari, A. (2018) 'Gambaran Intensitas Kebisingan di Wahana Bermain Indoor di Kota Padang', Jurnal Kesehatan Andalas, 7(2), p. 267.

Bureau of Labor Statistic. (2013) Bureau of Labor Statistic, US. D. of L. 2012

García-Gómez, F. J., González-Gaya, C. and RosalesPrieto, V. C. (2020) 'An Approach to Health and Safety Assessment in Industrial Parks'. Sustainability, 12(9), pp. 1-17

ICMM (2016) 'Good Practice Guidance on Occupational Health Risk Assessment', International Council on Mining and Metals, pp. 1-68.

International Labor Organization (2010) Sustainability through a competitive and responsible company (SCORE) Module 5. Jakarta: International Labor Office.

International Labor Organization (2013) The Prevention of Occupational Disease. Vol.13, International Labor Organization: pp. 641-645.

International Labour Organization (2014) 'A 5 STEP GUIDE for employers, workers and their representatives on conducting workplace risk assessments. Geneva: International Labour Office.

ISO 45001 (2018). Occoputional Health and Safety Assessment Series, OH \& Safety Management System Requirement.

Iqbal, M. I., et al. (2021) 'Hazards Identifications and Risk Assessment with Controls (HIRAC) in Oil Industry - A Proposed Approuch', Materials Today: Proceedings.

Kurniawidjaja, M (2012) Occupational Health Theory and Applications. Jakarta: UI Press.

Kranjak, K. (2018) 'Health Effect Associated with Occupational Exposure to Hand-arm or whole Body Vibration'. Journal of Toxicology and Environmnental Health - Parts B: Critical Reviews, 21 (5), pp. 320-334.

Laal, F., R, F. M. and Noorizadeh, N. (2017) 'Health Risk Assessment of Occupational Exposure to Harmful Chemical Agents in a Pesticide Manufacturing Plant', JOHE: Journal 
of Occupational Health and Epidemiology, 6(3), pp. 171-177.

Lestari, M., Purba, I. G. and Camelia, A. (2017) 'Penilaian Risiko Kesehatan Kerja di Bengkel Auto 2000', Jurnal Ilmu Kesehatan Masyarakat, 8(3), pp. 145-159.

Jayanti, M, D. K.., Sitorus, R. J. and Purba, I. G. (2011) 'Penilaian Risiko Kesehatan Kerja Faktor Fisik dan Faktor Kimia di Pusat Pengumpul Produksi (PPP) PT Pertamina ep Region Sumatera Feld Prabumulih', Jurnal Ilmu Kesehatan Masyarakat,2(3) pp. 167-172.

Ministry of Health (2015) 'Infodatin: Situasi Kesehatan Kerja', Jakarta: Ministry of Health of Republic of Indonesia.

Ministry of Manpower (2018) Regulation of the Minister of Manpower of the Republic of Indonesia Number 5 of 2018 tentang Keselamatan dan Kesehatan Lingkungan Kerja. Jakarta: Ministry of Manpower of the Republic of Indonesia..

Nugrahaeni, A. (2020) 'Health Risk Assessment In The Utility Area of Lubricant Production Limited Liability Company, The Indonesian Journal of Public Health, 15(2), pp. 224-235.

Pawin Vivid, R., Selvakumar, N. and Ruvankumar, M. (2020) 'Determination of Hazard in Truck Manufacturing Industry using Hazard Identification Risk Assessment Technique', Materials Today: Proceedings, 27(2), pp. 1858-1862.
Rizkiani, D. O. and Modjo, R. (2018) 'Health Risk Assessment of Workers at the Mining Company PT. HIJ Site in South Kalimantan: An Overview', KnE Life Sciences, 4(5), p. 616.

Rout, B., Sikdar, B. (2017). 'Hazard Identification, Risk Assessment, and COntrol Measures as an Effective Tool of Occoputional Health Assessment of Hazardous Process in an Iron One Palletizing Industry', Indian Journal of Occupational and Environmental Medicine, 21, 56 - 76

Saisandhiya, N. R. (2020) 'Hazard Identification and Risk Assessment in Petrochemical Industry', International Journal for Research in Applied Science and Engineering Technology, 8(9), pp. 778-783.

Susanto, A. and Mulyono, N. B. (2018) 'Risk Assessment Method for Identification of Environmental Aspects and Impacts at Ore Processing Industry in Indonesia', Journal of Ecological Engineering, 19(2), pp. 72-80.

Western Australia Department of Health (2006) 'Health Risk Assessment in Western Australia', pp. 1-20.

Zeinda, E. M. and Hidayat, S. (2017) 'Risk Assessment Kecelakaan Kerja Pada Pengoperasian Boiler Di Pt. Indonesia Power Unit Pembangkitan Semarang', The Indonesian Journal of Occupational Safety and Health, 5(2), p. 183. 